\title{
Japan's Strategy in Internationalization of Small and Medium Sized Firms: A Case Study of Japan Internship Program
}

\author{
Strategi Internasionalisasi Perusahaan Kecil dan \\ Menengah Jepang: Studi Kasus Japan Internship \\ Program
}

\author{
Firman Budianto \\ Indonesian Institute of Sciences
}

\begin{abstract}
The changing labor market following the economic and socio-cultural changes in Japan, on the one hand, drives the country to increase foreign workforces, including highly skilled foreign professionals. On the other hand, number of studies on global talents in Japanese workplace demonstrates a call for structural reforms in the Japanese firms as highly skilled global talents, from their own perspective, are struggling to integrate into Japanese firms due to multiple factors. By using qualitative data from document and content analysis, this present study contributes to the growing discourse on global talents mobility in the changing Japanese corporations by discussing, from Japan side, their strategies in dealing with the emerging needs of foreign workforces. Based on a case study of METI Japan Internship Program, this study finds that Japanese government in collaboration with Japanese firms start to promote an internship program for international young talents and make use of their cultural capital to not only support host companies' business expansion, but also to expand crosscultural exposure in the workplace and challenge the existing HRM practice of the companies. Being facilitated by the Japanese government, the program is beneficial for Japanese firms and may serve as a stepping stone for the students to work in Japanese firms in the future. This present study, therefore, suggests that global internship paves a way in channeling global talents to Japan and plays an increasingly crucial role in promoting emerging forms of internationalization within Japanese corporations.
\end{abstract}

Keywords: Global talent, Internationalization of Japanese firms, Japan Internship Program, Skilled migration

Pasar tenaga kerja yang berubah mengikuti perubahan ekonomi dan sosial-budaya di Jepang, di satu sisi, mendorong Jepang untuk memfasilitasi masuknya tenaga kerja asing, terutama, profesional asing terampil. Di sisi lain, sejumlah studi tentang talenta global di Jepang menunjukkan adanya urgensi reformasi struktural di perusahaan-perusahaan Jepang karena pekerja asing terampil tersebut menghadapi berbagai tantangan untuk berintegrasi ke perusahaan-perusahaan Jepang. Dengan menggunakan data kualitatif dari analisis dokumen, penelitian ini berkontribusi terhadap diskursus mobilitas talenta global dalam perusahaan Jepang dengan membahas, dari sudut pandang Jepang, strategi mereka dalam menghadapi peningkatan kebutuhan tenaga kerja asing terampil. Berdasarkan studi kasus Program Magang Jepang METI, studi ini menemukan bahwa pemerintah Jepang bekerja sama dengan perusahaan-perusahaan Jepang telah memulai program magang untuk talenta muda internasional dan memanfaatkan keterampilan mereka untuk tidak hanya mendukung ekspansi bisnis perusahaan Jepang, tetapi juga untuk mempromosikan komunikasi lintas budaya di tempat kerja dan mengritik praktik manajemen SDM perusahaan yang berjalan. Dengan dukungan Pemerintah Jepang, program ini bermanfaat bagi perusahaan Jepang dan dapat berfungsi sebagai batu loncatan bagi para peserta untuk bekerja di perusahaan Jepang di masa depan. Penelitian ini, oleh karena itu, menunjukkan bahwa program magang global membuka jalan bagi para latenta global untuk berkarier di Jepang dan semakin memainkan peran dalam mempromosikan internasionalisasi dalam perusahaan Jepang.

Kata-kata kunci: Internasionalisasi Perusahaan Jepang, Japan Internship Program, Migrasi terampil, Talenta Global 


\section{Japan's Strategy in Internationalization of Small and Medium Sized Firms: A Case Study of Japan Internship Program}

In early summer 2018, I attended METI Japan Internship Program information session in Tokyo. Organized by Pasona Global Japan in collaboration with a student organization of a university in Tokyo, the event aims to familiarize the students with Japanese government sponsored internship program and the goals it sets out. The organizer played a short promotional video regarding theprogram which includes some testimonies from both host companies and the interns. There was also a former intern presented to share her own experience and thought about the program.

According to Japan Ministry of Economy, Trade and Industry (METI n.d.), Japan Internship Program (Kokusai-sokushin Intanshippu Jigyō) or JIP aims to provide the interns opportunities to study the overseas business strategies at Japanese companies and acquire the skills and expertise of the host companies. For the Japanese firms, however, the program has three major purposes, namely (1) knowledge building for development and overseas business expansion, (2) changing awareness and experiencing cross-cultural communication through working with foreigners, and (3) network building with overseas universities aimed at securing foreign talent.

Long before the introduction of the JIP in 2016, Japanese Government has established in 1993 the Technical Intern Training Program (Gaikokujin Ginō Jisshū Seido) or TITP that shares similar goals with JIP to serve as a training platform for non-Japanese nationals. Aiming to contribute to the human resource of developing countries, the TITP allows young people from these countries to come to Japan as trainees to acquire specified skills through on-the-job training.

In 2017, the number of the TITP trainees reached about 308,489 or 21 percent of the 1,460,463 non-Japanese working in Japan (MHLW 2019). The TITP, moreover, has been expanded in April 2017, allowing the trainees who pass practical exam and meet certain qualifications to extend the maximum period of work from three to five years (MOJ \& MHLW 2017). Furthermore, the TITP is significant for Japanese industries as it facilitates the entry of the trainees into Japan as a 'stable labor force' (Kamibayashi 2015) for the employers who suffer from labor shortages and also considering TITP status as main legal procedure for securing less-skilled foreign workers in the country (Mazumi 2019).

Different from the TITP trainees who typically perform $3 \mathrm{D}$ jobs (demanding, dirty and dangerous) with low remuneration (e.g. Kamibayashi 2015; Komai 2017), the JIP seeks highly skilled foreign professionals living outside of Japan who are agreeing with the purpose of the program and willing to cooperate with Japanese businesses to achive the aims of the program. In a broader sense, this government-initiated internship program would be part of the responses by Japanese government to the country's changing domestic labor market and to the call for attracting more foreign professionals to come and work in the country.

In 2017, the job opening-to-applicant ratio in Japan hit 1.59, the highest ratio since records began in the 1974, while the unemployment rate falls to 2.4 percent which is the lowest since 1995 (MHLW 2018). In addition, Japan's total employment has been increasing steadily due to the recent economic expansion (OECD 2019) despite a decline in its working-age population. This changing labor market issues are crucial for Japan as the country needs a suficient number of working populations to support its economic growth and social security system. Furthermore, on May 7, 2012, Japanese government has introduced a points-based system that grants highly skilled foreign professionals an access to preferential immigration treatment (MOJ 2018) in order 
to promote the entry of global talents to the country. In this context, global talents, according to Oishi (2012), are not in demand only to stabilize the population but also to help Japan increase competitiveness in the global economy.

The Government of Japan's broad strategies on its changing labor market and the attempt to attract more global talents are, however, inseparable from the larger economic revitalization plans reflected on the Abenomics policy. The Abenomics which is initially started as a comprehensive policy package aimed at the revival of the Japanese economy has evolved into a broader blueprint for pro-growth socio-economic change (JapanGov 2019). One of its key visions related to the country's changing labor market is to foster productivity of individuals and society, by putting an emphasize on the people as the key actors in the economic activities. The government promotes three actions, i.e. (1) work-style reform, (2) human resource development, and (3) allowing participation of the women, the seniors, and the expatriates. Besides Abenomics, the Government of Japan (Prime Minister of Japan and His Cabinet 2016, 2018) has also been taking a further step to improve productivity by promoting inclusiveness and flexibility in the workplace that would allow the increasing participation of four groups of people: the women, the elderly, the disabled, and the foreigners, making it to focus on the 'people' in the economic activities.

Despite all these recent strategies, the participation of foreign professionals and global talents in Japanese workplace and Japan's labor market remains relatively small compared to the total workforces. The number of global talents in Japan experienced an increasing trend, from 33,000 in 1990 to 198,000 in 2010 (Oishi 2012). As of October 2018, there are 276,770 people working in the fields associated with professional or technical and specialized works (MHLW 2019) making it comprised 18.9 percent of the total 1,460,463 foreign workers in Japan. Despite this increasing number, however, many literatures on skilled foreign workers in the country mainly suggest a call for structural reforms within the Japanese firms (e.g., Liu-Farrer \& Hof 2018; Oishi 2012; Waldenberger 2016) as these people, from their point of view, are struggling to integrate themselves into Japanese workplace (e.g., Hof 2018; Moriya 2012; Oishi 2012).

Aside from global talents' point of view, this study, on the other hand, attempts to elaborate further the entry of global talents to Japan, the call for structural reforms within Japanese companies and the current phenomenon of internationalization of Japanese workplace from Japanese businesses' point of view. By putting Japan Internship Program (JIP) in the spotlight, this present study, therefore, discusses the current state of the JIP, examine how such internship program, as a recent initiative by the Japanese government to promote the internationalization of Japanese firms, facilitates the process of structural reforms within Japanese companies and, to what extent, affects the promotion of internationalization of Japanese workplace. Several research questions are amployed to achieve the aims of this study, i.e. how global talents, as interns, play a role in the host Japanese companies; how host companies take advantages from these global interns; and how would JIP affect the process of internationalization of Japanese companies in the future. Considering that in the near future, non-Japanese workers will be an integral and substantial part of Japan's labor pool (Liu-Farrer 2011), the research on how the businesess and the government of a developed yet culturally "homogeneous" country deals with the changing labor market, the entry of global talents, and the increasing call for structural reform within Japanese firms is increasingly significant. 


\section{Japan's Strategy in Internationalization of Small and Medium Sized Firms: \\ A Case Study of Japan Internship Program}

\section{Method}

This study employs qualitative method to investigate how Japanese governmentinitiated program promotes the entry of global talents to the country and facilitates the process of internationalization of Japanese firms. The primary data used in this study was collected from document and content analysis over the period of 2017 to 2019. I examined Performance Report of the JIP from Fiscal Year 2016 to 2018 and over 30 publicly available case studies from official Japan Internship Program webpage (https://internshipprogram.jp/theme/) both in Japanese and English. The case studies used in this present study are drawn from the actual examples of companies that have hosted foreign interns in fiscal year 2016, 2017, and 2018. They are organized under three themes based on the results that the companies have achieved, namely (1) overseas business expansion, (2) new business development innovation, and (3) crosscultural management.

This present study, moreover, employs three stages of research design. The first stage is literature review where previous studies on skilled-migration, migration to Japan and Japanese workplace were carefully examined. The following stage is data collection and analysis. In doing so, I made use of publicly available materials, such as white paper published by Japanese government, as the primary data. I accessed Japanese government official webpages to collect data from Japanese side, both original Japanese version or English official translation. The final stage is data analysis where the data collected from document and content analysis are intertextually analyzed to see the relationship between Japan Internship Program and the internationalization of Japanese companies.

\section{Global Talents and Internationalization of Japanese Firms}

The discourse of internationalization of Japanese firms is, however, inseparable with the discourse of internationalization of education (e.g., Yano 2000), global human resources (e.g., Yonezawa 2014) and internationalization of human resource management in Japanese MNCs (e.g., Sekiguchi, Jintae Froese, \& Iguchi 2016) following the call for structural reforms within Japanese firms (e.g., Liu-Farrer \& Hof 2018; Oishi 2012; Waldenberger 2016). The internationalization of education in Japan emerged around 1980 along with the rapid expansion of exports of Japanese high technology products (Yano 2000), the promotion of English learning at secondary school through the Japan Exchange and Teaching (JET) Program, and the 300,000 International Students Plan (Yonezawa 2014) set out by Japan's Prime Minister Yasuo Fukuda in July 2008. The plan aimed to attract 300,00o international students by the year 2020 as part of a "global strategy" to open up Japan to the rest of the world (MEXT 2008). This plan to attract more international students is significant for expanding the flows of people, goods, money and information between Japan and other regions (MEXT 2008). Moreover, from long term standpoint, it provides the country a new source of skilled workers since an increasing number of non-Japanese students look for employment in Japan after graduation (Hennings \& Mintz 2015) and for that reason they became one major source of the recruits of Japanese companies (Liu-Farrer 2009). 
Following the plan to attract more international students, furthermore, Japan also set out The Project for Establishing Core Universities for Internationalization, or Global 30 Project, aiming to create an environment that makes it easier for international students to study in Japanese universities (MEXT 2017). In this sense, this global strategy and all the attempts to create international environment in Japanese education share the similar goals to create Japanese people mentality as global human resources and to increase competitiveness of Japanese people in the globalized world by making use of the existance of those foreign people to the country. In Japan's business world, however, the situation is quite challenging for non-Japanese talents. Foreign workers, especially global talents, according to Oishi (2012), are facing institutional and non-institutional barriers in the Japanese companies, such as challenge in career development and inflexible labor market, that limit their long-terms settlement in Japan. She puts an emphasize on the importance of reforms in corporate structures and business practices of Japanese corporations. In similar point, Moriya (2012) finds that difficulties in inter-cultural communications as well as gaps in career development are the most challenge for global talents in Japan. Furthermore, in her research on young European professionals in Japan, Hof (2018) argues that the migrants' economic and cultural capital do not necessarily benefits them in the process of incorporating and accelerating themselves in the Japanese society and workplaces. From more structural point of view, however, several studies also suggest that structural reforms within Japanese firms are increasingly needed and inevitable. The limits of immigration policies and inflexible labor market (Oishi 2012), the ethnocentric staffing system (e.g., Kasahara, 2014) and the Japanese-style human resource management practices (Sekiguchi et al., 2016) make Japanese companies unattractive to non-Japanese employees and highly skilled foreign professionals.

While these studies suggest a call for the structural reform within Japanese companies, the studies on the internationalization of human resource management (HRM) argue that many large Japanese companies, compared to newly emerging firms, are hesitant to internationalize their HRM practices (Sekiguchi et al. 2016), as large firms still have adequate supply of human resources that makes them to have little incentive to change (Liu-Farrer \& Hof 2018). Furthermore, despite of the size of the company, internationalization of Japanese firms requires the reform of the Japanese management style and the use of language within the company to achieve multicultural company Kameda (2013).

Internationalization of Japanese firms also can be categorized into two, namely 'internal internationalization' at Japanese headquarters (HQ) and 'external internationalization' in foreign subsidiaries (Sekiguchi et al. 2016). Among the latest practice that challenges traditional HRM in Japanese firms is the global recruitment by Japanese companies to hire new graduates from overseas. Such practice does not only play a key role in bringing in global talents to Japan, but also is seen as a new method of international human resource development that challenges the existing Japanese way of human resource management (Conrad \& Meyer-Ohle 2017, 2018).

\section{Japan Internship Program: An Overview}

The Government of Japan through the Ministry of Economy, Trade and Industry (METI) firstly initiated Japan Internship Program in fiscal year (FY) 2016. Given 


\section{Japan's Strategy in Internationalization of Small and Medium Sized Firms: A Case Study of Japan Internship Program}

the Japanese official name, Kokusai-sokushin Intanshippu Jigyou (Internship Project for the Promotion of Internationalization), the program aimed at promotion of internationalization in small-medium sized Japanese firms due to their lack of experience in working with foreign talents and their lack of network (METI, 2019). Foreign nationals of developing countries who have been approved by the screening committee are eligible to participate in this program as Interns. In particular, this program requires the applicants to have language proficiency in Japanese (JLPT level $\mathrm{N}_{3}$ or higher) or in English, should be at least 20 years of age and not older than 40, and have to be able to submit a certificate of graduation or a letter of recommendation from the university or from the company for those who are working. To participate in this program, the applicants also must be agreeing with the purpose of this program and willing to cooperate with Japanese businesses.

According to (METI n.d.), the program has three main goals for Japanese firms, namely: (1) knowledge building for development and overseas business expansion, (2) changing awareness and experiencing cross-cultural communication through working with foreigners, and (3) network building with overseas universities aimed at securing foreign talent. For the interns, it provides opportunities to study overseas business strategies at Japanese companies and to acquire the skills and expertise of the companies. Overall, the program is carried out in the following schedule: information sessions, recruitment, examination and selection, final matching, actual internship period, and submission of reports. In implementing the program, METI entrusts PASONA and JETRO who work closely with the host companies, create a screening committee, and carry out all the procedures.

Since the first implementation of the program in FY 2016, METI have carried out evaluations for both sides of the participating foreign interns and the host Japanese companies. Evaluation of the participants, on the one hand, demonstrated that the program has successfully drawn attention of many young foreign nationals to apply, making selection process for the intern more competitive.

Figure 1. Overall evaluation of Japan Internship Program from interns' side (METI)

\begin{tabular}{|l|l|l|l|l|l|l|l|l|}
\hline \multirow{2}{*}{$\begin{array}{c}\text { Fiscal } \\
\text { Year }\end{array}$} & \multicolumn{2}{|c|}{ Foreign Nationals } & \multicolumn{4}{|c|}{ Top 4 Interns Nationalities } & \multicolumn{3}{c|}{ Evaluation } \\
\cline { 2 - 10 } & Applicant & Interns & Vietnamese & Chinese & Indonesian & Thai & $\begin{array}{c}\text { Match } \\
(\%)\end{array}$ & $\begin{array}{c}\text { Satisfaction } \\
(\%)\end{array}$ \\
\hline 2016 & 9,367 & 103 & 30 & 25 & 13 & 10 & 85 & 96 \\
\hline 2017 & 12,687 & 120 & 33 & 22 & 19 & 15 & 96 & 98 \\
\hline 2018 & 10,830 & 225 & 66 & 25 & 34 & 32 & 91 & 97 \\
\hline
\end{tabular}

Among 9,367 applicants in 2016 there were only 103 selected interns while in 2017 there were 12,687 candidates for 120 positions. In 2018, the committee increased the position for interns to 225. The selected interns mainly came from East and Southeast Asia where Vietnam, China, Indonesia, and Thailand are among the top in number. However, interns also came from other continent, such as Europe and Central America (3 people in 2016), Africa (4 people in 2017), while in 2018, the interns came from Europe, Africa, and South America region increased to 23 people. 
Furthermore, the overall evaluation also shows most of the interns considered themselves matched with the host companies and were satisfied with the program in general. A significant number of the interns have the Japanese and English proficiency to a certain level as shown in the following figure.

Figure 2. Interns' Linguistic Abilities (METI)

\begin{tabular}{|c|l|l|l|l|l|l|l|}
\hline \multirow{2}{*}{$\begin{array}{c}\text { Fiscal } \\
\text { Year }\end{array}$} & \multicolumn{3}{|c|}{ Japanese Language Proficiency (\%) } & \multicolumn{4}{c|}{ English Proficiency } \\
\cline { 2 - 8 } & $\begin{array}{c}\text { Business } \\
\text { Level }\end{array}$ & $\begin{array}{c}\text { Daily } \\
\text { Conversation }\end{array}$ & Others & Native & $\begin{array}{c}\text { Business } \\
\text { Level }\end{array}$ & $\begin{array}{c}\text { Daily } \\
\text { Conversation }\end{array}$ & Others \\
\hline 2016 & 31.1 & 40.8 & 28.1 & 9.7 & 43.7 & 31.1 & 15.5 \\
\hline 2017 & 36.7 & 36.7 & 26.7 & - & 62.5 & 30.8 & 6.7 \\
\hline
\end{tabular}

Approximately one third of the interns speak business level Japanese and about half of them speak business English. The figure in FY 2018, however, is excluded in the following table since it has different evaluation system and parameter to measure the language proficiency of the interns. The following figure, furthermore, demonstrates the overall evaluation from participating firms.

\section{Figure 3. Overall evaluation of Japan Internship Program from host companies' side (METI)}

\begin{tabular}{|l|l|l|l|l|l|l|l|}
\hline \multirow{2}{*}{$\begin{array}{c}\text { Fiscal } \\
\text { Year }\end{array}$} & \multicolumn{2}{|c|}{$\begin{array}{c}\text { Participating } \\
\text { Company }\end{array}$} & \multicolumn{4}{c|}{ Top 3 Business Sectors } & \multicolumn{2}{c|}{ Overall Evaluation } \\
\cline { 2 - 9 } & Applicant & Host & Service & $\begin{array}{c}\text { Wholesale } \\
\text { and Retail }\end{array}$ & Manufacturing & Match (\%) & Satisfaction (\%) \\
\hline 2016 & 219 & 71 & 16 & 11 & 10 & 98 & 92 \\
\hline 2017 & 263 & 90 & 17 & 19 & 25 & 93 & 100 \\
\hline 2018 & 304 & 196 & 24 & 38 & 65 & 94 & 97 \\
\hline
\end{tabular}

The evaluation from host institutions' side indicates that overall, the number of applicants and host firms increased significantly over three years of the implementation of the program. In 2018, for instance, the number of host companies doubled from 90 in 2017 to 196. The overall satisfaction of host companies even reached $100 \%$ in 2017 even though match evaluation slightly decreased in the same period. The top business sectors remained the same during three consecutive years, namely service industry, wholesale and retail, and manufacturing. The location of the companies includes all regions and major islands of Japan with the majority are located in Kanto area.

Figure 4. Scale and status of overseas operations of host companies (METI)

\begin{tabular}{|c|c|l|l|l|l|l|l|c|}
\hline \multirow{2}{*}{$\begin{array}{c}\text { Fiscal } \\
\text { Year }\end{array}$} & \multicolumn{3}{|c|}{ Scale of Business (number of employees) (\%) } & \multicolumn{3}{c|}{ Status of Overseas Operation (\%) } \\
\cline { 2 - 9 } & $\begin{array}{c}\text { up } \\
\text { to } 9\end{array}$ & 10 to 99 & $\begin{array}{c}100 \text { to } \\
499\end{array}$ & $\begin{array}{c}500 \text { to } \\
1000\end{array}$ & $1000+$ & Ongoing & Planned & Not Planned \\
\hline 2016 & 33.8 & 49.3 & 12.7 & 1.4 & 2.8 & 55.9 & 32.5 & 11.9 \\
\hline 2017 & 28.9 & 42.2 & 25.6 & 2.2 & 1.1 & 71.1 & 24.4 & 4.4 \\
\hline 2018 & 24.0 & 49.0 & 21.9 & 4.1 & 1.0 & 51.5 & 37.3 & 11.2 \\
\hline
\end{tabular}




\section{Japan's Strategy in Internationalization of Small and Medium Sized Firms: \\ A Case Study of Japan Internship Program}

More than half of the host companies are small-medium sized firms with employees below 100 people. A significant number, about $85 \%$, of the companies have planned or carried out overseas operation. The host companies also must understand and agree with the purpose of the program, have interest in expanding and developing new overseas business, and be able to work in harmony with interns. The JIP welcomes not only private firms, but also industry associations and non-profit corporations to participate in the program as host companies. During the internship period, the host companies are responsible for the interns, providing work guidance and support for living arrangements. The detailed qualitative data on Japanese firms' view is discussed in the following section.

\section{Beyond Overseas Business Development}

Recent changes in Japan's labor market following the economic and socio-cultural changes drive the country to deal with the increasing need to recruit highly skilled foreign professionals and urge the government to formulate a strategy to adjust many aspects in its business environment. In this study, Japan Internship Program is seen as the answer by the Japanese government in collaboration with Japanese businesses to such challenges. The program which initially aims at promotion of internationalization in mainly local small-medium sized Japanese firms has main goals to build knowledge, raise awareness, and build network. Upon analyzing case studies from the host companies, however, this study argues that from the companies' perspective, the interns' cultural and social skills worked most in all goals. This study shows that host companies have gained some new insight from the interns for business development and beyond.

In order to keep up the recent slight economic growth of the country, corporations in Japan need to find a way to face the tough global business competition. Furthermore, the shrink of Japan's domestic market urges the country to find other market opportunities. Accelerating business development and market expansion to emerging market such as Southeast Asian countries might, therefore, be inevitable. By making use of interns' cultural skills, the host firms received new know-how, to some extent, on how they might proceed in doing business overseas. Some of the know-how and insights from the interns are, for instance, fresh and various ideas from a young non-Japanese perspective which Japanese would not have thought of (case in Manufacturing; Construction; Scientific Research, Professional and Technical Services); new access to previously inaccessible market by doing online marketing and interviews with overseas customers in English (case in F\&B Services); and very specific know-how on the halal certification for Muslim (case in Manufacturing).

Besides the know-how for overseas business development, the host companies also confirmed that there were several changes in employees' awareness toward crosscultural communication as well as working situation during the internship period. Such changes in crosscultural communication, for instance, can be described as the following. One case study shows that the employees on the floor where the interns were started using English naturally (case in Manufacturing; Service), while the other 
shows that the employees learned from the interns to become more proactive and more self-assertive (case in Manufacturing). There is also an interesting case of the interns challenged employees to spoke frankly their mind (case in Manufacturing; Information and Communications).

For the management side of the companies, the involvement of young foreign talents in the organization goes beyond gaining the know-how of overseas business development. It, however, raises awareness on how is it to employ foreign talents and change the way Japanese management see the foreign talents' potentials. From the case study, the participation of highly skilled foreign interns in the workplace increases skills in managing workers of diverse background and serves as a great opportunity to rethink the ways of human resource management, even towards Japanese employees, based on what information foreign nationals would need and what concerns they would have (case in Wholesale and Retail Trade). In addition, most companies have learned foreigner's perspective on being employed, considered that internship provides a chance to see the skill-sets of the foreign talents, which cannot be seen during the job-hunting process, and start to believe that foreigners are adequate employee candidates. One case demonstrates that the intern's working ability, data collection ability, presentation skill are beyond host companies' expectation (case in Service). Another interesting case shows that a firm has scheduled to recruit an Indonesian national in the following year. The firm found the internship program as very educational experience preceding the actual employment (case in Manufacturing). Furthermore, regarding network building, a company confirmed that its intern facilitated in forging a relationship with an overseas university (case in Construction) and a possible collaboration in developing market in intern's home country in the future (case in Service).

From the interns' perspective, however, this internship program might be a stepping stone for them to pursue a real professional career in Japan in the future. During the internship period, the interns learned not only Japanese business culture, but also Japanese society and custom in general. This internship opportunity might shape the interns' future career decision whether to pursue professional work in Japan. This internship program, therefore, play an increasingly important role not only in bridging Japanese firms with overseas university but also in securing foreign human resource for the firms. This attempt to establish cooperation with overseas university, mainly to supply Japanese firms with some candidates, add to the discourse of emerging migration infrastructures (e.g., Conrad \& Meyer-Ohle 2018; Liu-Farrer \& Tran 2019).

\section{Emerging Forms of Internationalization of Japanese Firms}

This study examines government-initiated Japan Internship Program in facilitating the process of internationalization of small-medium sized Japanese firms that participate in the program. Different from large Japanese firms which still have adequate supply of human resources (Liu- Farrer \& Hof 2018), small-medium sized companies in this study are in need of highly skilled foreign workers to assist them in overseas business development. However, apart from these goals, the JIP grants the participating companies access to more than business development know-how but also to internationalization of the companies. 


\section{Japan's Strategy in Internationalization of Small and Medium Sized Firms: A Case Study of Japan Internship Program}

The JIP facilitates the internationalization of host companies in these following ways. Firstly, it promotes diversity within the workplace through cross-cultural exposures. The existance of foreign interns are followed by the increasing awareness of other cultures and different religion as experienced by the host companies. It, moreover, allows the majority ethnic Japanese employees in small-medium sized firms to experience the meaning of diversity, something they would otherwise not encounter without the presense of foreign interns. The interns, during their temporary employment in the host companies, helped to vanish, to some extent, the linguistic and cultural wall between local employees and the foreigners. Oishi (2012) noted that many corporations are worried about incorporating non-Japanese into the workplace because of the language barrier and not so many Japanese firms have adopted English as their official language or established a bilingual policy. Therefore, it is the time for Japanese organizations to start communicating with simple English, and gradually promote bilingual in the workplace. The use of English is beneficial not only for the purpose of overseas business expansion, but also to widen the local staff perspectives and to bring color to the workplace where majority speaks only Japanese. Moreover, as global talents oftentimes face difficulties in inter-cultural communications (Moriya 2012), this cross-cultural exposure is significant for the Japanese companies to achieve the goal of internationalization. Furthermore, the emergence of diversity and international cultures allow the Japanese workplace to become more vibrant and, in this sense, the diverse background of people working together also tend to result in creativity (Florida 2012), a skill-set that is crucial for business development nowadays.

Secondly, the diversity brought by JIP paves the way to the changes in the human resource management (HRM) practices of the small-sized companies. It allows the firms to not only create novel directions in their human resource procurement activities, but also to challenge their current HRM practices. Since they have already got the bigger picture of how to employ non-Japanese staff, it will be easier for the companies to employ the foreigner in the future. The firms gain access to what kind of expectations non-Japanese would have and what kind of working condition they want. The internship program paves the way for the firms to employ foreign talents and change the way Japanese management sees the foreign talents' potentials as they have stopped assuming that only Japanese staff could do the work they do. In this context, the ways the firms conduct their HRM practices are also challenged by the actual experience they encountered during the internship period, such as particular conditions due to religious reason. It urges the companies to formulate a new HRM system that accommodate everyone in the increasingly diverse workplace. This JIP program promotes internationalization of Japanese firm from inside where changes in human resources management practices is implemented and promoted within the company. In a larger context, these case studies from the internship program may eventually pave a way to a better understanding on how internationalization of Japanese firms should be institutionalized.

\section{Conclusion}

In this study, foreign professionals is not only on demand for their linguistic skills and cultural competencies to support the overseas business expansion (Liu-Farrer 2011), but also to promote internationalization within Japanese firms through their cultural capital and possible future network building and collaboration through their social 
capital. Interns' capitals might be inseparable part of the long-term internationalization of the Japanese firms as the interns might be part of the future foreign employees of the host companies. In addition, the foreigners are indispensable for overseas business development and for this reason, highly skilled foreign professionals would be invaluable assets for the Japanese small-medium sized companies who aiming at global expansion. To accept highly skilled foreign professionals, the firms need to change their awareness so that mutual understanding could be formed.

This study, on the one hand, demonstrates that Japanese corporations are increasingly needing foreign skilled workers to support their overseas business while in the same time also working on the internationalization within the Japanese business. On the other hand, this study also suggests what strategy the Japanese firms should take in response to the increasingly need of global talents. From case studies of Japan Internship Program by METI, this study finds that Japanese firms are starting to promote internship program for young foreign nationals and make use of their capital not only to support host companies' business expansion, but also to expand crosscultural exposure in the workplace and challenge the existing HRM practice of the companies. In a larger context, these case studies from the internship program may eventually pave a way to a better picture of internationalization of Japanese firms and can be a role model on how such process should be adopted and institutionalized in other firms in order to increase competitiveness and productivity as the Government plan to achieve by 2020.

Overall, this study suggests that global internship paves a way in channeling global talents to Japan and plays an increasingly crucial role in promoting new form of internationalization within Japanese corporations. If the firms hope to become more international, they should be the one who inisiate the change and start to reform the way they do the business. In this sense, the existance of foreign staff would only serve as facilitator and it would not become a help if the Japanese side does not have the willing to change their usual business practices. As it is more difficult for big enterprises to change their work culture and systems since they do not face critical labor shortage (Liu-Farrer \& Hof, 2018), it is the small-medium enterprises that have a bigger chance to reforms their business environment in order to face the competition in global economy not merely to secure their human resource. In order to change the work culture in Japan both the company as a system and employees as individuals should play a role. Due to the limited data used, this study, however, suggests that a further study on the emerging new actors involved in today's migration of global talents to Japan as well as study on dynamics of internationalization of Japanese corporations are worth pursuing.

\section{References}

\section{Books and Chapter in Books}

Florida, R. 2012. The Rise of the Creative Class: Revisited. New York: Basic Books.

Kamibayashi, C., 2015. Gaikokuj̈n Rōdōsha Ukeire to Nihon Shakai: Ginō Jisshū Seido no Tenkai to Jirenma [Accepting foreign workers in Japanese society: The dilemma of a temporary immigrants program]. Tokyo: Tokyo Daigaku 
Japan's Strategy in Internationalization of Small and Medium Sized Firms:
A Case Study of Japan Internship Program

Shuppankai.

Kasahara, T., 2014. Nihon kigyo no gurobaru jinteki sigen kanri [Global human resource management of Japanese corporations]. Tokyo: Hakuto Shobo.

Komai, H., 2017. Imin Shakaigaku Kenkyū: Jittai Bunseki to Seisaku Teigen 19872016 [A study of sociology of migration: Empirical research and policy proposal 1987-2016]. Tokyo: Akashi Shoten.

\section{Journals and Online Journal}

Conrad, H., \& Meyer-Ohle, H., 2017. "Overcoming the ethnocentric firm? - foreign fresh university graduate employment in Japan as a new international human resource development method", The International Journal of Human Resource Management, 1-19. https://doi.org/10.1080/09585192.2017.1330275

Conrad, H., \& Meyer-Ohle, H., 2018. "Brokers and the Organization of Recruitment of 'Global Talent' by Japanese Firms-A Migration Perspective”, Social Science Japan Journal, 21(1), 67-88. https://doi.org/10.1093/ssjj/jyxo32

Hennings, M., \& Mintz, S., 2015. “Japan's Measures to Attract International Students and the Impact of Student Mobility on the Labor Market", Journal of International and Advanced Japanese Studies, 7, 241-251.

Hof, H., 2018. “Worklife Pathways' to Singapore and Japan: Gender and Racial Dynamics in Europeans' Mobility to Asia”, Social Science Japan Journal, 21(1), $45-65$.

Kameda, N., 2013. "Japanese Global Companies: The Shift from Multinationals to Multiculturals”, Global Advances in Business Communication, 2(1), 1-18.

Liu-Farrer, G., 2009. "Educationally Channeled International Labor Mobility: Contemporary Student Migration from China to Japan", The International Migration Review, 43(1), 178- 204.

Liu-Farrer, G., 2011. "Making Careers in the Occupational Niche: Chinese Students in Corporate Japan's Transnational Business", Journal of Ethnic and Migration Studies, 37(5), 785-803. https://doi.org/10.1080/1369183X.2011.559718

Liu-Farrer, G., \& Hof, H., 2018. "Big Firm Syndrome (Ōtebyō): The Problems of Japanese Firms and the Problematic Elite Aspirations", Journal of Asia-Pacific Studies (Waseda University), 34(5), 65-84.

Liu-Farrer, G., \& Tran, A. H., 2019. "Bridging the Institutional Gaps: International Education as a Migration Industry", International Migration, 57(3), 235-249. https://doi.org/10.1111/imig.12543

Mazumi, Y., 2019. "What shapes local demand for 'guest worker' migrants in Japan? The case of the seafood processing industry", Contemporary Japan, 31(1), 2-20. https://doi.org/10.1080/18692729.2018.1563346

Moriya, T., 2012. "Nihon kigyō no ryūgakusē nado no gaikokujin saiyō he no kōsatsu" $\square$ (Investigation of the recruitment of international students into Japanese firms), Japanese $\square$ Labor Studies, 623, 29-36. 
Oishi, N., 2012. "The Limits of Immigration Policies: The Challenges of Highly Skilled Migration in Japan”, American Behavioral Scientist, 56(8), 1080-1100. https://doi.org/10.1177/0002764212441787

Sekiguchi, T., Jintae Froese, F., \& Iguchi, C., 2016. "International human resource management of Japanese multinational corporations: Challenges and future directions", Asian Business \& Management, 15(2), 83-109. https://doi. org/10.1057/abm.2016.5

Waldenberger, F., 2016. "In-House Careers: A Core Institution of the Japanese Firm in Need of Reform”, Journal of Strategic Management Studies, 8(1), 23-32.

Yano, M., 2000. "Gurobarizeishon to kyoiku" [Globalization and education], The Journal of Educational Sociology, 66, 5-19.

Yonezawa, A., 2014. "Japan's Challenge of Fostering "Global Human Resources": Policy Debates and Prectices”, Japan Labor Review, 11(2), 37-52.

\section{Online Publications}

JapanGov, 2019. "Abenomics: For future growth, for future generations, and for a future Japan" [online]. In https://www.japan.go.jp/abenomics/_userdata/ abenomics/pdf/1901_abenomics.pdf [Accessed March 17 2019]

METI, n.d. "Japan Internship Program"[Kokusai-sokushin Intanshippu Jigyō] [online]. In https://internshipprogram.jp/ [Accessed September 20 2018]

METI, 2019. "We are looking for participant companies for Japan Internship Program" [Kokusaisokushin Intanshippu Jigyō sankakigyo boshuuchuu]" [online]. In https://www.meti.go.jp/press/2019/05/20190523001/20190523001.html [Accessed June 30 2019]

MEXT, 2008. "Outline of the Student Exchange System: Study in Japan and Abroad" [online]. In http://www.mext.go.jp/a_menu/koutou/ryugaku/o81210/o01. pdf [Accessed June 12, 2016]

MEXT, 2017. "Gurobaru 30 to ha?"[What is global 30?] [online]. In http:// www.mext.go.jp/component/a_menu/education/detail/__icsFiles/ afieldfile/2017/o3/30/1383779_01.pdf [Accessed October 28 2018]

MHLW, 2018. “Japan's Labor Market (1990-2018)”.

MHLW, 2019. "Gaikokujin Koyō Jōkyō" no Todokede Jōkyō Gaiyōban (Heisei 3o-nen 10-gatsumatsu genzai)" [Summary of the reporting of "employment situation of foreigners" (as of October 2018)] [online]. In https://www.mhlw.go.jp/ content/11655000/000472891.pdf [Accessed July 22 2019]

MOJ, 2018. "Points-based System for Highly-Skilled Foreign Professionals" [online]. In http://www.immi-moj.go.jp/newimmiact_3/en/system/index.html [Accessed July 23, 2018]

MOJ \& MHLW, 2017. "New Technical Intern Training Program" [online]. In http://101.110.15.201/content/o01223972.pdf [Accessed July 23 2019]

OECD, 2019. "The Future of Work: How does Japan compare? OECD Employment 
Japan's Strategy in Internationalization of Small and Medium Sized Firms:

A Case Study of Japan Internship Program

Outlook 2019" [online] in https://www.oecd.org/japan/Employment-OutlookJapan-EN.pdf [Accessed July 22 2019]

Prime Minister of Japan and His Cabinet, 2016. “The Japan's Plan for Dynamic Engagement of All Citizens" [online]. In https://www.kantei.go.jp/jp/singi/ ichiokusoukatsuyaku/pdf/plan2.pdf [Accessed July 20 2018]

Prime Minister of Japan and His Cabinet, 2018. "Mirai Toushi Senryaku 2018" (Future $\square$ Investment Strategy 2018). 